STUDIA HUMANITATIS JOURNAL, 202I, I (I), pp. 192-208

ISSN: 2792-3967

D01: https://doi.org//0.5370I/shj.vlil.22

\title{
THE CATHOLIC CHURCH IN THE CZECH LANDS DURING THE NAZI OCCUPATION IN 1939-1945 AND AFTER ${ }^{1}$
}

\author{
LA IGLESIA CATÓLICA EN LOS TERRITORIOS CHECOS DURANTE LA OCUPACIÓN NAZI \\ ENTRE LOS AÑOS 1939-1945 Y DESPUÉS
}

\author{
Marek Smid \\ Charles University, Czech Republic \\ ORCID: 0000-000 I-86I3-8673
}

smidma@seznam.cz

(c) (1) (8)

\begin{abstract}
This study addresses the religious persecution in the Czech lands (Bohemia, Moravia and Czech Silesia) during World War II, when these territories were part of the Bohemian and Moravian Protectorate being occupied by Nazi Germany. Its aim is to demonstrate how the Catholic Church, its hierarchy and its priests acted as relevant patriots who did not hesitate to stand up to the occupying forces and express their rejection of their procedures. Both the domestic Catholic camp and the ties abroad towards the Holy See and its representation will be analysed. There will also be presented the personalities of priests, who became the victims of the Nazi rampage in the Czech lands at the end of the study. The basic method consists of a descriptive analysis that takes into account the comparative approach of the spiritual life before and after the occupation. Furthermore, the analytical-synthetic method will be used, combined with the subsequent interpretation of the findings. An additional method, not always easy to apply, is hermeneutics, i.e., the interpretation of socio-historical phenomena in an effort to reveal the uniqueness of the analysed texts and sources and emphasize their singularity in the cultural and spiritual development of Czech Church history in the first half of the 20th century.
\end{abstract}

Keywords: Catholic Church; German occupation; Czech lands; Czechoslovakia; 1939-1945.

\footnotetext{
Resumen | El presente estudio aborda la persecución religiosa en los territorios checos (Bohemia, Moravia y la Silesia checa) durante la Segunda Guerra Mundial, momento en el que estos territorios formaron parte del protectorado de Bohemia y Moravia, bajo la ocupación de la Alemania nazi. El objetivo de este texto es demostrar cómo la Iglesia Católica, su jerarquía y sus sacerdotes actuaron como relevantes patriotas que no dudaron en plantar cara a las fuerzas ocupantes y expresar su rechazo a los procedimientos de aquéllas. Se analizará, además, el papel de la Iglesia católica en el plano doméstico y sus lazos exteriores con la Santa Sede. Finalmente, se presentarán las figuras de los sacerdotes víctimas de la represión nacionalsocialista en los territorios checos. La metodología básica de este estudio consiste en el análisis descriptivo desde una perspectiva comparativa de la vida espiritual antes y después de la ocupación alemana. Además, el método analítico-sintético será empleado en combinación con la interpretación de los hallazgos realizados. A todo ello cabe añadir un último método, no siempre fácil de aplicar, como es la hermenéutica. Esto es, la interpretación socio-histórica de fenómenos en un esfuerzo por revelar el carácter único de los textos analizados y de las demás fuentes, asi como por enfatizar el particularismo del desarrollo cultural y espiritual de la Iglesia checa y su historia a lo largo de la primera mitad del siglo XX.
}

Palabras clave: Iglesia Católica, Ocupación alemana; Territorios checos; Checoslovaquia; 1939-1945.

${ }^{1}$ Recibido/Received: 02/05/202 I

Aceptado/Accepted: 07/06/202I 


\section{| Introduction |}

The core of this study deals with the persecution of religious life in the Czech lands during World War II, when the Czech territories, as the Protectorate of Bohemia and Moravia (1939-1945), were occupied by Nazi Germany. Its aim is to point out how the Catholic Church, its hierarchy and the priests acted as prominent patriots who did not hesitate to oppose the occupying power and express their disagreement with its procedures. Both the domestic Catholic field and the links it established with the Holy See and its representation will be analyzed. The article will also present the context of the Church's policy in Czechoslovakia after 1945, which was similar to that of other Eastern European countries of the Soviet bloc, where the Communists came to power.

The text is mainly based on Vatican archives (especially the Historical Archive of the Secretariat of State of the Holy See) and Czech archives (especially the Archive of the Ministry of Foreign Affairs of the Czech Republic and the Archive of the Office of the President of the Republic), as well as published sources and editions, which are confronted with the extensive existing literature, especially of Czech provenance. Based on the knowledge of all these materials, the article focuses on the Catholic Church in the Czech territories and its contacts with the Holy See facing the totalitarian regimes of the 20th century, first Nazi (1939-1945) and then communist ideology (1948-1989).

The basic method consists of a descriptive analysis that takes into account a comparative approach of the spiritual life before and after the occupation. Furthermore, the analytical-synthetic method will be used, combined with the subsequent interpretation of the findings. An additional method, not always easy to apply, is hermeneutics, i. e. the interpretation of socio-historical phenomena in an effort to reveal the uniqueness of the analysed texts and sources and emphasize their singularity in the cultural and spiritual development of the Czech Church history in the 20th century.

\section{| Czechoslovakia before the occupation |}

The Czechoslovak state was established on October 28, 1918 and a month later a Republic was proclaimed. The basis of the country's internal organization was a system of pluralist parliamentary democracy, based on political parties, most of which already existed before World War I. Despite many political, economic and social difficulties, Czechoslovakia led by President Tomas Garrigue Masaryk remained the only democratic country in Central Europe until the late 1930's.

Religious conditions were quite complicated. The population of Czechoslovakia was strongly radicalized by the terrifying experience of World War I and its aftermath, which contributed to the harsh opposition to the Catholic Church and the symbols of Catholicism in the Czech lands. The Church was perceived by the liberal and socialist sectors of society as complicit in the centuries-old of Austrian oppression and its organization was associated with the former Monarchy.

Thus, part of Czech society spoke out against the power of the Austrian Habsburgs and the influence of the Catholic Church, of which several historical monuments fell victim. After the war, a million inhabitants of the country left the Church, of which one part 
joined the newly formed independent Czechoslovak Church in Rome, and another remained without religion. However, in the late 1920s, this flight from the Catholic Church stopped and the situation calmed down.

A free democratic state, the so-called First Czechoslovak Republic, lasted only twenty years. Its existence ended up with the Munich Conference in September 1938, which led to the resignation of its borderland inhabited mainly by Germans in favour of the Nazi Third Reich. Because of the military superiority of Germany, the international isolation of Czechoslovakia and the passivity of the Western ally of France, the Central European Republic did not dare to fight, although it had a solid military arsenal and enthusiasm to fight of most of its population. When Pope Pius XI learned of the results of the conference, he described the Czechoslovak sacrifice as a gift of peace to the whole world (Drabek, 1967, p. 245). ${ }^{2}$

The changes on the map of Europe, which began to take place in early October 1938, did not only reflected Berlin's new political ideas, but also changed the existing religious order. In the post-Munich territorial divisions, Czechoslovakia lost an area of more than $40000 \mathrm{~km}^{2}$, i. e. almost a third of the state territory. The occupation accounted for almost $30000 \mathrm{~km}^{2}$ in the Czech lands, $10000 \mathrm{~km}^{2}$ in Slovakia and $10000 \mathrm{~km}^{2}$ in Subcarpathian Ruthenia. Czechoslovakia also lost almost five million inhabitants (Karnik, 2003, p. 625).

Besides territorial losses, the Church administration changed too: half of the parishes of the Olomouc archdiocese, one-third of the parishes of the diocese of Ceske Budejovice and two-thirds of the Litomerice diocese belonged to the Third Reich. The Berlin Nuncio Cesare Orsenigo took over their spiritual administration and communication with local priests. Some parishes remained without pastors, as some of them fled to Germany and some to the Czech inland. ${ }^{3}$

On October 5, 1938, under pressure from Germany, Edvard Benes abdicated for his presidency, travelling two weeks later to Great Britain and then to the United States of America, where he lectured at the University of Chicago. Because the new Czechoslovak government started to search for a way to communicate with Germany, hostile currents to democracy began to prevail in the country's political life.

Knowing this, the Secretary of State of the Holy See Eugenio Pacelli encouraged Prague Archbishop, Czech Primate and Cardinal Karel Kaspar not to rush, but to wait with the possible adjustment of the diocesan borders and to temporarily entrust vicar-generals with the administration of the foreign parts of dioceses. On 16 and 23 November, Karel Kaspar was twice received by Pope Pius XI, who had observed the Czechoslovak situation with deep interest and sympathy. ${ }^{4}$

After the Munich Conference, there also intensified the pressure to resolve the Slovak question and the idea prevailed to settle the problem of Slovakia's position within the country. On November 22, 1938, the Parliament passed the law on the autonomy of Slovakia. The achievement of autonomy for Slovakia was also the victory of Slovak

\footnotetext{
${ }^{2}$ Archiv Ministerstva zahranicnich veci Ceske republiky v Praze [The Archive of the Ministry of Foreign Affairs in Prague], Political Reports Fund - Vatican, 1938, Radimsky 3. 10. 1938.

${ }^{3}$ Archivio Storico. Sezione per i rapporti con gli stati (Segreteria di Stato), Cecoslovacchia, IV periodo, fascicolo I88, ff. 36-4I, Ritter to Pacelli 9. 10. 1938, resp. fascicolo 190, f. 9, Ritter to Pacelli 7. 10. 1938

${ }^{4}$ The Archive of the Ministry of Foreign Affairs in Prague, II section MFA political - I Ordinary Record Office (1918-1939), box file 34, Radimsky 28. II. 1938.
} 
political conservative Catholicism led by Hlinka's Slovak People's Party (Vass, 20I I, p. $31)^{5}$

The new Slovak autonomous government of Karol Sidor was appointed on II March 1939. However, under pressure by the German side and Slovak radicals, it refused to declare an independent Slovak state. Thereupon, when Karol Sidor the Nazis' candidate for the liquidation of Czecho-Slovakia failed, Adolf Hitler turned to Jozef Tiso, the exPrime Minister of the autonomous Slovak government, and invited him to an official meeting to Berlin on March I3, 1939 (Smid, 2014, p. 229).

Adolf Hitler expressed there the categorical requirement to the Slovak delegation: either they would instantly declare an autonomous Slovak state with German guarantees, or the führer would leave the country to fend for itself, which de facto meant leaving the country to Hungarian aspirations. In this situation, Jozef Tiso summoned the Slovakian Parliament which declared the Slovakian state on March 14, 1939. The mentioned Tiso became the Prime Minister, Vojtech Tuka Deputy Prime Minister, Karol Sidor Interior Minister and Ferdinand Durcansky Foreign Minister (Letz, 20I2, Pp. 56-62).

\section{| German occupation of the Czech lands |}

The rest of the Czecho-Slovak Republic, which retained a kind of independence, was liquidated on 15 March 15, 1939, when German troops reached Prague and the Reich Chancellor Adolf Hitler occupied the Czech lands. On the same evening the German leader arrived in Czech capital and a day later he issued a decree on the establishment of so-called Protectorate of Bohemia and Moravia as a formal autonomous and selfgoverning part of the German Empire. Therefore, this territory did not have its own foreign representation and was not allowed to maintain international relations (Rychlik, 202I, p. 184).

The State President Emil Hacha and the protectorate government headed by its chairman (the protectorate governments were gradually headed by Rudolf Beran, Alois Elias, Jaroslav Krejci and Richard Bienert) became the representatives of the Czech protectorate administration. These men were preferred by the Nazis to the Czech fascist organizations and their untrustworthy leaders who could disrupt the relatively stable situation in the protectorate. The degree of autonomy narrowed over time.

Most of the executive powers of the occupation administration were soon taken over by the German State Ministry for Bohemia and Moravia headed by Karl Hermann Frank as Minister of State. The state secret police (gestapo), units of the occupying army (wehrmacht) and other German security forces operated in the protectorate and became the mainstay of the occupying power to punish all enemy activities.

The Berlin Nuncio Cesare Orsenigo informed the Holy See about the situation in the Czech lands in his reports of March 15 and 18, 1939. In his first report, he informed Secretary of State Luigi Maglione of the fact that German troops had occupied Prague and would probably occupy the rest of the territory during that day, adding that Adolf

${ }^{5}$ Archivio Apostolico Vaticano, Archivio Nunziatura Cecoslovacchia, busta 80, fascicolo 643, ff. 12-13, Visek to Ritter 2. I2. 1938. 
Hitler and his Foreign Minister Joachim von Ribbentrop had departed for the occupied territory (Blet, 1970, p. 98).

In his second report from Berlin dated three days later, he wrote about the methods of occupation, Emil Hacha's night meeting with Adolf Hitler in Berlin, the attitude of Italy towards the occupation of the Czech Lands, reactions from France, the situation in Slovakia, reactions of the German population, etc. (Machula, 1998, p. 36). ${ }^{6}$ It was mainly France that, after the annexation of Czechoslovakia, tried to make the Holy See protest against the German steps. However, the Pope refused to do this and thus did not oppose the political actions of March 1939.

Nuncio Saverio Ritter was forced to leave Prague in April 1939 when he returned to Italy. This had not been the case after Munich, when the Holy See had firmly supported a democratic Czechoslovakia but took place as soon as Nazi authorities interfered in the Protectorate of Bohemia and Moravia. The tense situation in the country was observed by Berlin Nuncio Cesare Orsenigo who informed the highest Vatican circles. The Apostolic Nuncio was deported from Prague by the interference of a foreign power, Germany, not due to the severance of diplomatic relations between the Holy See and Czecho-Slovakia or because of his dismissal by the Vatican (Nemecek, 2008, p. 248). ${ }^{7}$

He had been working in the country since the autumn of 1935 when he left his mission in Switzerland. He was certainly not a newcomer to the Czechoslovak affairs, but he was already known in Prague from his earlier work there in the second half of the 1920s. Until the end of the 1930s, Giuseppe Burzio, an Italian priest and diplomat, held the post of his secretary. By choosing Ritter's personality, the Holy See indicated that he really cared about good relations with Czechoslovakia (Zapletova, 2 I I, p. 350).

Saverio Ritter came to Czechoslovakia at an extremely tight period. The application of the modus vivendi had not yet been closed, tensions between national minorities had been fully manifested, Slovaks' demands for autonomy had intensified and the country had been going through the parliamentary and presidential elections that year. International tensions had also boosted events in Central Europe. In this situation, the Czechoslovak envoy to the Holy See and the Apostolic nuncio in Prague included in their reports from the mid-1930s more and more events of European events and the radicalization of authoritarian and totalitarian movements.

It was obvious that the development in Czechoslovakia and the organization of Central Europe are connected vessels, which also depended on international events and the political situation in the surrounding states. They were no longer democratic countries and therefore did not intend to help Czechoslovakia. Poland and Austria became authoritarian regimes in the second half of the 1920s, Germany in the early of 1930s, Hungary and Romania at the end of this period. Little Entente, alliance formed in 1920 and I 921 by Czechoslovakia, Romania and Yugoslavia, collapsed with the rapid growth of German power in 1938. The view of the Holy See had therefore expanded into detailed analyses of events in Germany, Poland, Austria, Italy, France, the Soviet Union and other world powers (Lora and Simionati, 1995, PP. 1074-II27). ${ }^{8}$

\footnotetext{
Ibidem, Orsenigo to Maglione 18. 3. 1939.

${ }^{7}$ Archiv Narodniho muzea [Archive of the National Museum], fund Eduard Jelen, box 2B: Eduard Jelen, Ceskoslovensko a Vatikan za Prvni republiky (nepublikovany rukopis) [Czechoslovakia and the Vatican during the First Republic (unpublished typescript)], p. 4I9.

${ }^{8}$ Acta Apostolicae Sedis. Commentarium officiale (I 937), annus XXIX, volumen IV. Roma: Typis Polyglottis Vaticanis, pp. I 45-I88. 
Also, the new Pope Pius XII expected Saverio Ritter to resume his diplomatic activities after the end of World War II so he did not entrust him with any new mission during the war but expected events to develop in the hope that he would send him back to Czechoslovakia after the conflict. The Czechoslovak envoy to the Holy See Vladimir Radimsky was also forced to close his embassy in Rome and return to occupied Prague after March I5, 1939 (Halas, 2004, p. 574; Smid, 2014, pp. 225-235).

The Prague Nunciature was not liquidated immediately, but continued to function. From July 1939, its operations were conducted by Raffaele Forni, Secretary of the Nunciature. He was subsequently transferred to the Berlin Nunciature, from where he travelled to Prague or Olomouc every ten days, until being prevented from doing so by the Germans in 1942. From 1942 to 1945, Raffaele Forni served as Secretary of the Nunciature in Bratislava (Machula, 1998, p. 60).

\section{| The Establishment of the Protectorate and the attitude of the Czech people |}

Since the beginning of the German occupation, there had been spontaneous manifestations of the Czech population's disapproval of the protectorate administration, which were heard on important days, participation in national pilgrimages or a boycott of transport. The population considered the occupation of the Czech lands a manifestation of Nazi will and a threat to the existence of the Czech nation. Therefore, a wave of patriotism spread through the country, which helped to overcome the harsh humiliation. In November 1939, all Czech universities in the country were closed and many university students were sent to the concentration camps (Stribrny, 2009, p. 98).

The vast majority of the Czech population felt hostility towards the Nazi occupiers, expecting their imminent defeat at war, and through it the liberation of their homeland. The opposite current was formed by those who cooperated with the Germans. These included groups of Czech fascists, various types of traitors, informers and confidants, as well as collaborators from the ruling protectorate classes seeking to gain a share in government and decision-making, various unprincipled careerists and those who chose to survive at all costs. Until the Nazi invasion to the Soviet Union in June 194I, members of the communist party of Czechoslovakia did not support the resistance because they had called the conflict from their perspective a struggle between the imperialists.

A copybook example of Czech collaboration with Nazi protectors was Emanuel Moravec, Minister of Education, who openly cooperated with the Germans. On the contrary, there were many brave men among Czechoslovak Catholics, often members of the Catholic sports organization Orel, who left the country and joined the Czechoslovak troops abroad. From all of them, the most important were the Czech and Slovak paratroopers trained in the United Kingdom who carried out a military attack on the Deputy Reich Protector Reinhard Heydrich in Prague in May 1942 to whom he fell victim a few days later (Sustek, 2019; Kmoch, 2018).

Many people in the ranks of the protectorate administration, who often collaborated with the resistance, also refused the German intentions. Among them, there was also the second Prime Minister of the Protectorate General Alois Elias, who maintained 
contacts with domestic and foreign resistance, and a number of officials from the protectorate administration, the police, the gendarmerie and officers of the government army. Many of them were arrested, imprisoned or executed by the Nazis for their resistance activities (Sebek, 20I4, p. 106).

\section{|The Church affairs |}

There was a more serious friction between the Nazi authorities and the Holy See in Czech lands in connection with the issue of succession after the death of Bishop Simon Barta in Ceske Budejovice whose life ended on May 2, 1940. After his decease, the Holy See successfully resisted pressure from the Nazis to fill this episcopal see and to separate the Czech and Moravian dioceses from their original homeland, agreeing only to their interim administration by the German and Austrian bishops.

The Holy See rejected their arguments, stating that the Czech lands were not a part of the Nazi Third Reich, when, moreover, the territory with two thirds of Czechs belonged to a Czech Church representative. However, the German government was adamant and rejected the Czech candidate even if the vicar-general of the diocese were of German origin. After all it was the Catholic Church who won this struggle, as the post of Bishop of Ceske Budejovice remained vacant until the summer of 1947, when Professor of Pastoral Theology Josef Hlouch became the ninth bishop in South Bohemia (Stribrny, 2009, p. 104; Sebek, 2014, p. 105).

Other disputes over vacant episcopal posts in Prague after the death of Archbishop Karel Kaspar in April 194I and in Brno after the death of Bishop Josef Kupka in June of the same year resonated similarly. Their occupation was also resolved only after the end of World War II. President Edvard Benes, the head of democratic Czechoslovakia abroad, also appreciated the detention tactics of the Catholic Church and the reluctance to comply with the Nazi insistence on the part of the Holy See (Sebek, 2008, p. 28).

Attacks against priests and religious communities became a visible sign of Nazi repressive policy in the protectorate, which intensified after the arrival of the Deputy Reich Protector Reinhard Heydrich to Prague in September 194I. One of those arrested in that time was the Metropolitan Canon of St. Vitus cathedral in Prague, former Secretary of the Apostolic Nunciature and Papal Prelate Otakar Svec. From September 1942 he was interned in the concentration camp in Mauthausen near Linz and from December 1944 on in Dachau near Munich (Smid, 206, Pp. 47-56; Ludvik, 1946, p. I2; Hoffmann, 1946, p. 338).

A similar case was that of the priest Vaclav Stverak, who went through several concentration camps, in which he showed physical and mental resilience, when, for example, he accepted the beating of an older Polish clergyman. After the World War II, he was one of the important witnesses to the Nuremberg trials with war criminals (Vodickova, 2013, p. 362).

During the war, the importance of Sunday sermons and festive services increased, which Christians often understood as hidden parables of the present. The clergy played an extremely important role in the first months and years of the occupation, encouraging, supporting, comforting, advising and warning the Czech people. Their words, now even of deeper meaning, connected presence with eternity, bringing salvation, giving hope and 
emphasizing love. The spiritual books, religious songs or liturgical texts became popular wartime readings (Stribrny, 2009, Pp. 108-109).

The harsh persecution measures were extremely strong, especially for Jews in the Czech lands, of whom 120000 lived here at the turn of the 1930s and 1940s. At first, Jews were ostracized, excluded from all political and social life, deprived of the opportunity to study, travel, perform a number of occupations, then marked with a yellow star with the inscription Jude/ Jew and interned in Terezin, whose ghetto served as a concentration camp from November 194I. From there, the arrested Jews were deported to extermination concentration camps, especially in Poland. After mass transports from January 1942 to October 1944, most Jews from the Czech lands perished in the local gas chambers - 79000 out of 118000 people (Rothkirchnenova, Schmidt-Hartmannova and Dagan, I99I; Petruv, 20I I; Gruner, 2019).

\section{| Contacts of the Government-in-exile with the Holy See |}

The first attempts for a rapprochement between both sides were already undertaken in the fall of 1940. On November 15 of that year, Edvard Benes asked Apostolic nuncio in London William Godfrey if he could pay him an official visit to inform him of the religious situation in Czechoslovakia before and after the war. However, the Roman Curia replied negatively to William Godfrey and suggested postponing the meeting under the current circumstances. ${ }^{9}$

On June 10, 194I, President Edvard Benes sent another letter to Vatican diplomat William Godfrey, emphasizing that Czechoslovakia "is based on the principle of legal continuity and this principle should be applied to Czechoslovakian-Vatican relations" (Smid, 20I5, p. 404).

After the international situation changed in 1943 - especially after the first significant military successes of the Allies and after some foreign states ceased recognizing the Munich Agreement - Edvard Benes, through New York Archbishop Francis Joseph Spellman, American President Franklin Delano Roosevelt and the British government, submitted a memorandum to the Holy See, offering to restore the diplomatic relations (Machula, 1998, p. 65; Kamenec, Precan and Skorvanek, 1992, pp. 152-I 53; Kaplan, 1993, p. 8).

Friedrich Muckermann, a German Jesuit and writer, also intervened in the negotiations, trying to convince the Holy See that their dismissive, or rather passive, approach could lead to the deterioration of the Church's situation in post-war Czechoslovakia. Czech political circles felt indignant, particularly by the appointment of Nitra Bishop Karol Kmetko as Archbishop in May 1944, which they regarded as a violation of modus vivendi from 1928. The Vatican opposed them declaring that they had appointed him as Archbishop ad personam. ${ }^{10}$

\footnotetext{
${ }^{9}$ Archiv Kancelare prezidenta republiky [Archive of the Office of the President of the Republic], fund Office of the President of the Republic, Vatikan, Nr. 16 594/II-5/45, The Question of the Restoration of Diplomatic Relations between CSR and the Vatican, Maixner 4. 9. 1945

${ }^{10}$ Archive of the Office of the President of the Republic, fund Office of the President of the Republic, Vatican, Nr. I6 594/II-5/45, The Question of the Restoration of Diplomatic Relations between CSR and the Vatican, Maixner 4. 9. 1945.
} 
After World War II, Edvard Benes's unanswered letters to the Holy See of I94I and 1943 were the reasons why Czechoslovakia did not trust the Vatican's policy and its diplomatic activities." Nevertheless, the Holy See's attitude towards the person of Edvard Benes changed in the mid-1930s, when he ceased to be considered by the Vatican circles a dangerous freemason, but was rather appreciated as a democratic and pacifist politician. His stance won him the support of the Holy See during the presidential elections in December 1935.

The Holy See only showed more willingness at the end of World War II, when, in September 1944, they requested the Czechoslovakian side for a visit to the Vatican by Jan Sramek, the head of the Czechoslovak government-in-exile. Through Jaromir Machula, a young priest and Secretary of the Czechoslovak National Committee, Czechoslovakia refused to take the initiative and asked the Vatican to respond to the two memorandums of 194 I and 1943, as no relationship can be established without it. ${ }^{12}$

From March 1945, the Holy See waited for the liberation of Milan, where Saverio Ritter was staying, so that negotiations on the restoration of diplomatic relations could be launched. At the same time, intermediary Jaromir Machula arrived in London on March 23, 1945 to negotiate about the rapprochement of the Holy See and Czechoslovakia (Machula, 1998, p. 97).

On April 16, 1945, Prime Minister Zdenek Fierlinger informed Soviet Envoy Valerian Zorin about the establishment of diplomatic relations between Czechoslovakia and the Holy See, assuring him that the Vatican had expressed interest in the resumption of diplomatic relations with Prague on the basis of recognition of the new political situation in Europe. However, Czechoslovakia refused to simply restore Ritter's initial mission that had been aborted due to the Holy See's recognition of the Slovak Republic in late March 1939. On the other hand, the Holy See had not suspended diplomatic relations with Czechoslovakia. Although Nuncio Ritter had been expelled from Prague upon the interference of foreign powers, he had not been received in Bratislava and had used the title of Apostolic Nuncio to Prague throughout the war (Machula, 1998, P. I38; Nemecek; 2008, p. 254).

\section{| The Church Affairs after World War II |}

Regarding the number of Czechoslovak priests executed, tortured and imprisoned as a result of their imprisonment in the Dachau concentration camp, seventy-six died there. Among the most famous priests who survived the suffering of this camp were, among others, the later Archbishop of Prague Josef Beran, Jesuit Adolf Kajpr, Premonstratensian Augustin Machalka, Politician and Priest Bohumil Stasek, Collaborator of the Apostolic nunciature in Prague Otakar Svec, later Bishop of Litomerice Stepan Trochta, Priest Alois Tylinek or Church historian and Priest Bohumil Zlamal.

Almost one hundred and fifty clergymen were imprisoned in the camp of Terezin, eight of whom died there and at least another twenty-two in concentration camps and prisons, where they were transferred. In total, more than three hundred and seventy priests

\footnotetext{
' The Archive of the Ministry of Foreign Affairs in Prague, fund Representative Office Vatican, 1946-1947, Schwarzenberg I4. 3. 1946.

${ }^{12}$ Archive of the Office of the President of the Republic, fund Office of the President of the Republic, Vatican, Nr. 16 594/II-5/45, The Question of the Restoration of Diplomatic Relations between CSR and the Vatican, Maixner 4. 9. 1945.
} 
were persecuted during World War II, two hundred and sixty of whom ended up in concentration camps. Eight of them were directly executed and another nearly sixty died in concentration camps and prisons (Benes, 197I, p. 257; Hoffmann, 1946, Pp. 330-340; Ludvik, 1946, p. II).

The Czech Catholic Church emerged from World War II with high credit, when none of the bishops or priests were guilty of cooperating with the Nazi power. Many brave priests were also found among Sudeten Catholics, including those who paid for their resistance with their lives. The Reich Concordat with Germany did not apply in the border areas, where the Nazi attacks against the Church continued with no inconvenience (Sebek, 2008, p. 26).

After World War II, Saverio Ritter returned to Prague, but only as an Internuncio (officially from the summer of 1946), which was related to the overall change of the political climate in Czechoslovakia. The representation of the Holy See changed from a Nunciature to an Internunciature and the doyen of the diplomatic corps became the Soviet Envoy Valerian Zorin. At the beginning of 1946, Frantisek Schwarzenberg, a young experienced diplomat and a participant of the domestic resistance, became the Czechoslovak Ambassador to the Holy See. Unfortunately, soon, in August 1946, he was replaced by the communist diplomat Artur Maixner (Balik and Hanus, 2007, p. I8).

In January 1948, the Apostolic Internuncio Saverio Ritter, whose protracted illness had kept him from Czechoslovakia for many months, travelled to Rome for treatment and never returned to Prague. He was replaced by the Charge d'affaires Gennaro Verolino as the head of the Vatican mission in Czechoslovakia (Balik and Hanus, 2007, p. 19).

On May 15, 1948, shortly after the communist coup d'état, Pope Pius XII sent a letter to Czechoslovakian bishops, in which he thanked them for their congratulations on the $10^{\text {th }}$ anniversary of his pontificate, and asked them to be brave and firm in those difficult times:

These difficulties can be faced only by whipping up even more religious fervor. Passionate with this fervor and trusting in God's help, strive together for God's sake in these difficult circumstances. Shining by your words and your own example, protect the principles of the Gospel, defend the rights of the Church and the souls of the faithful entrusted in your care, and cultivate unquestioning obedience and devotion to the Holy See that is always based on the unwavering promises of God."13

The Holy Father concluded his letter with a wish: "We, in fatherly solicitude, beg in many prayers for heavenly help for the beloved nations of Czechoslovakia, and closely follow every event in your country, wishing only for that which can save your dear ones..." (Vasko, 1990, p. 17).

The pope's warning voice was not an isolated fear of the Holy See towards the power of Moscow, but it was also intended to address the people of Eastern European countries. The sovietisation of this part would mean the end of the existence of the Catholic Church. However, Pius's significant success in clashing with communist politics in Italy in April 1946, before the parliamentary elections, where the pope clearly instructed voters who to vote for, did not find adequate echoes in Central and Eastern Europe and Pius XII. From this part of Europe, the Pope was gradually informed about

${ }^{13}$ Archive of the National Museum, fund Eduard Jelen, box 8, Pius XII I5. 5. 1948. 
the failures of political Catholicism, thus reducing the chances of manipulating Eastern European Catholicism.

\section{| The communist struggle against the Catholic Church |}

On January 19, 1949, Czechoslovakian bishops complained to President Klement Gottwald about the tense relations between the State and the Church, to which he had also contributed by his attitude (Letz, 2007, pp. 604-609). It was not the last critical letter addressed to the communist powers. Memorandums and letters by Czechoslovakian Bishops were also issued on March 23, 1949, April 29, 1949, May 17, 1949, June 15, 1949, July 27, 1949, October 21, 1949, etc.

When, in the fall of 1948, Gennaro Verolino went on a vacation, he was temporarily deputized for during his absence from Czechoslovakia by Giuseppe Sensi, Officer of the Secretariat of State, in the rank of charge d'affaires. It is possible that the Holy See tried to resolve the deadlocked Czechoslovakian-Vatican negotiations through personnel changes, so they replaced Verolino by Sensi, an experienced Diplomat of the Secretariat of State (Kukanova, 20I4, p. 65). ${ }^{14}$

Giuseppe Sensi sent a personal letter to Foreign Minister Vladimir Clementis on January 28, 1949, in which he complained about the illegal persecution of the Church by the communist regime, which sought to rid it of its freedom. He informed Vladimir Clementis that in 1948 many Catholic magazines and papal encyclicals had been prevented from publication. Giuseppe Sensi went on the offensive when he stated that the State sought to prevent the Church from carrying out its inalienable rights and duties (Vasko, 1990, p. 58; Kaplan, 1993, p. 59).

On February 17, 1949, Czechoslovakian ordinaries met with the Archbishop of Prague Josef Beran to discuss further proceedings in the confrontation with communist power. Sensi probably also attended the meeting, and it was he who suggested waiting for the return of Olomouc Archbishop Josef Karel Matocha from Rome before shaping any strategy. However, when Josef Karel Matocha returned on March 4, he had no clear instructions from the Holy See for the upcoming clash with the communists (Kaplan, 1993, p. 63).

In the spring of 1949, Gennaro Verolino returned to Prague, replaced Giuseppe Sensi and again took over the administration of the Internunciature as Charge d'affaires, but he was recalled from Czechoslovakia as persona non grata in the summer of the following year. In March 1950, the last Vatican diplomat Ottavio de Liva was expelled from the country. Before the Episcopal Conference in Stary Smokovec in Slovakia from March 22 to 23, 1949, bishops met in the Prague Internunciature, where Archbishop Josef Beran and Charge d'affaires Gennaro Verolino asked Stepan Trochta, Bishop of Litomerice, not to make concessions to the communists (Kaplan, 1993, p. 64).

After a bugging device was found at the Episcopal Conference, negotiations between the Church and the State came to a deadlock. Bishops gradually began to differ. One wing was represented by the intransigent nucleus centered around Josef Beran who had the

\footnotetext{
${ }^{14}$ Archive of the Office of the President of the Republic, fund Office of the President of the Republic, Vatican, Nr. 107 655/48, The Apostolic Nunciature in Czechoslovakia, Kordos 29. 10. 1948; Archive of the Ministry of Foreign Affairs in Prague, fund Representative Office Vatican, 1948-1950, Maixner 6. 10. 1948.
} 
support of the Holy See and some priests and who refused to withdraw from their demands. The second wing, focused on Stepan Trochta, was inclined to reach an agreement with the government. The latter apparently had the support of the majority of the bishops. It was only in mid-June that Gennaro Verolino received Prague Archbishop Josef Beran and four Church dignitaries to mutually coordinate the reaction of the Church to the Catholic action prepared by the State (Vasko, 2004, p. 140).

Based on secret reports, the communists came to the conclusion that Charge d'affaires Gennaro Verolino had encouraged bishops to oppose an agreement with the government and to enforce direct negotiations between the government and the Vatican - instead of the discussions between the communists and the favored new Church hierarchy and the National Front. In July 1949, they therefore decided to end Verolino's mission and remove him as an undesirable person (Machula, 1998, p. 172).

Paolo Bertoli, proposed by the Vatican as Verolino's successor as an active diplomat of the Holy See who had gained his experience from his missions in Yugoslavia, France, Haiti, the Dominican Republic and Switzerland, was not accepted by the Czechoslovakian side (Vasko, 1990, p. 6I).

After endless delays, the Vatican suggested another successor to Gennaro Verolino Opilio Rossi. However, he too was not accepted by Czechoslovakia after several months of screening his credentials. Therefore, the interests of the Holy See were only represented in Czechoslovakia by Legation Secretary Ottavio de Liva, former Secretary to the Vienna Internunciature who had become Sensi's Secretary in November 1948. However, Czechoslovakia did not even recognize him as Charge d'affaires. ${ }^{15}$

It was Ottavio de Liva who, in 1949, travelled around Czechoslovakia and encouraged individual ordinaries to be active. He was in especially close contact with the Archbishop of Prague, Josef Beran, to whom he interpreted the encouragement of the Holy See and gave him advice regarding negotiations with communist offices. According to available reports, between January and March 1950, he visited him three times (!). ${ }^{16}$

The communist regime subsequently proceeded with the internment of Czech and Slovakian Bishops. As a result, the Archbishop of Prague Josef Beran, Hradec Kralove Bishop, Moric Picha, Olomouc Archbishop, Josef Karel Matocha, Ceske Budejovice Bishop, Josef Hlouch, Brno Bishop, Karel Skoupy, Litomerice Bishop, Stepan Trocha, and many other priests, e. g. Karel Otcenasek and Frantisek Tomasek, were interned within a short time (Casaroli, 200I, p. I3I).

In December 1950, Stanislav Zela, Auxiliary Bishop of Olomouc, was sentenced. In January 195I, three Slovakian priests - Jan Vojtassak, Bishop of Spis, Michal Buzalka, Auxiliary Bishop of Trnava and Military Vicar, and Pavol Peter Gojdic, Bishop of Presov (Eparchy) - were given severe sentences for treason (Letz, 200I). However, these were not the last victims of the communist regime.

\footnotetext{
${ }^{15}$ Archive of the Office of the President of the Republic, fund Office of the President of the Republic, Vatican, Nr. I26 656/48, The Apostolic Nunciature in Czechoslovakia, Kordos II. II. 1948; Archive of the Ministry of Foreign Affairs in Prague, fund Representative Office Vatican, 1948-1950, Maixner 6. 10. 1948

${ }^{16}$ Archive of the Ministry of Foreign Affairs in Prague, fund Representative Office Vatican, 1948-1950, Objections to the Activities of de Liva, without date.
} 
The government initiated the creation of a new Church hierarchy comprised of chapter vicars, who were to replace the original group of bishops. In late February 1949, the presidium of the Central Committee of the communist party discussed the situation of the Catholic Church in Czechoslovakia. They concluded that the Holy See - or rather its representatives in Prague, Charge d'affaires Ottavio de Liva and Czechoslovakian bishops - should be accused of the "Cihost Miracle". ${ }^{17}$ The hateful seditious campaign thus turned in particular against Ottavio de Liva, accusing him of inventing the "Cihost Miracle". On March 16, they ordered him - as an instigator of the hostile Vatican policy - to leave the country within three days.

Although communist Czechoslovakia officially did not suspend diplomatic relations with the Holy See, this actually happened. Shortly afterwards, Ilja Rath, Czechoslovakian Envoy to the Holy See, left his office without any official notification of the suspension or cessation of diplomatic relations with foreign countries. He successfully completed his mission - de facto breaking off diplomatic relations between Czechoslovakia and the Vatican.

\section{| Conclusion |}

Although we speak about a relatively short period, we must realize that the contacts between Czechoslovakia and the Holy See differed in time and did not create a homogenous line, since they were different at the beginning of the war, at its end and at the end of 1940s as well. There were both the tight liaisons and the periods when there was almost no contact, mainly shortly after 1939. They were on the rise after 1945 when the Czechs contacted the high officials in the Roman Curia.

Although the Protectorate of Bohemia and Moravia brought the Catholic Church to its knees and brought about the physical liquidation of many priests and religious, it strengthened the internalization of religion and the Catholic faith among many Czech citizens. At that time, the Holy See successfully resisted pressure from the Nazi authorities to separate the detached areas of the Sudetenland from the Czech and Moravian dioceses and agreed only to their interim administration by the German and Austrian bishops. The Holy See consistently refused to fill a vacancy in three episcopal thrones in the Czech lands - in Prague, Ceske Budejovice and Brno - which became vacant during the Protectorate. They were occupied only after World War II when Czechoslovak diplomatic relations with the Vatican were resumed. This did not happen at the pre-war level in the form of an Apostolic Nunciature but only at the Apostolic Internunciature, i. e. at a diplomatically lower level.

As it has been said, the efforts to establish diplomatic relations between the Holy See and the Czech exile were initially unsuccessful. The Vatican only showed a more positive attitude towards the end of World War II, when the priest and secretary of the Czechoslovak National Committee Jaromir Machula arrived in London to contribute to the mutual rapprochement. When the Apostolic Internuncio Saverio Ritter reached Prague in the spring of 1946, mutual relationships were restored, but shortly after the

\footnotetext{
${ }^{17}$ The event of Cihost miracle happened on II December 1949, during the third Sunday in Advent, in the Church of the Assumption of the Virgin Mary in the village of Cihost near Havlickuv Brod in Czechoslovakia. The alleged miracle was used by communist authorities as a pretext for antireligious repression. It was the priest Josef Toufar who was tortured and died during the investigation of the event.
}

SHJ, I (I) (202I) pp. 192-208. ISSN: 2792-3967 
communist coup d'etat in February 1948 with expulsion of all Vatican diplomats from the country definitely broken.

The communists' campaign against the Church in Czechoslovakia was a logical and wellthought-out plan of aggressive communist policy aimed at seizing power. Access to churches, especially Catholic ones, did therefore not differ from access to other political groups. However, after leftist slogans about a just society turned out to be empty, collaborating Catholic action, whose prestige in Church circles declined sharply, as ineffective, and schism in Church circles as insufficient, the regime decided to demonstrate its power, based primarily on irrational arguments (Church as an anticommunist and imperialist institution or the Vatican spy network) and reflected only the current power superiority of the state apparatus.

The totalitarian ideologies of the 20th century that dominated the Czech lands, first Nazi and later communist, represented the unprecedented injustice perpetrated against innocent priests and monks. The false accusations were based on completely unjust fabricated causes and were related to their work in the Catholic Church, which, with an emphasis on individual values and human dignity, represented a strong anti-regime opposition to both totalitarians.

Diplomatic relations between Czechoslovakia and the Holy See were suspended for almost half a century. They were restored no sooner than in 1990 when Giovanni Coppa, an Italian Church dignitary and Officer of the Secretariat of State, arrived in Prague. He became the last Nuncio to Czechoslovakia and the first Nuncio to the Czech Republic. He held this post until 200I, when he was appointed as Canon of St. Peter's Basilica in the Vatican and six years later was created Cardinal. In 200I, he was replaced by Erwin Josef Ender, a German Church dignitary and diplomat, who had served as Apostolic Nuncio to the Baltic States before his arrival in Prague. In 2004, after he was charged with leading the Apostolic Nunciature in Berlin, Vatican Diplomat Diego Causero replaced him. The current Apostolic Nuncio to Prague is Giuseppe Leanza, an experienced diplomat and Church dignitary of the Holy See.

\section{| References |}

Acta Apostolicae Sedis. Commentarium officiale (I937), annus XXIX, volumen IV. Roma: Typis Polyglottis Vaticanis.

Balik, S., Hanus, J. (2007). Katolicka cirkev v Ceskoslovensku 1945-1989 [The Catholic Church in Czechoslovakia 1945-1989]. Brno: CDK.

Benes, J. (197I). Kaine, kde je tvuj bratr? Medailonky ceskych katolickych knezi - obeti fasismu [Cain, Where is Your Brother? Medallions of Czech Catholic Priests - Victims of Fascism]. Prague: Ceska katolicka charita.

Blet, P. (Ed.) (1970), Actes et Documents du Saint Siège relatifs à la Seconde Guerre Mondiale, Orsenigo to Maglione I5. 3. 1939. Vaticano: Libreria Editrice Vaticana.

Casaroli, A. (200I). Tryzen trpelivosti. Svaty stolec a komunisticke zeme (1963-1989) [The Torment of Patience. The Holy See and the Communist Countries (1963-1989)]. Kostelni Vydri: Karmelitanske nakladatelstvi. 
Drabek, J. (ed.) (1967). Z casu nedlouho zaslych. Vzpominky Dr. Morice Hrubana [From the Recent Past. Memories of Dr. Moric Hruban]. Rome: Krestanska akademie.

Gruner, W. (2019). Pronasledovani Zidu v Protektoratu Cechy a Morava. Mistni iniciativy, centralni rozhodnoti, reakce Zidu 1939-1945 [Persecution of Jews in the Protectorate of Bohemia and Moravia. Local initiatives, central decisions, reactions of Jews 1939-1945]. Prague: Academia.

Halas, F. X. (2004). Fenomen Vatikan. Idea, dejiny a soucasnost papezstvi. Diplomacie Svateho stolce. Ceske zeme a Vatikan [The Vatican Phenomenon. The Idea, History and Present of the Papacy. Diplomacy of the Holy See. The Czech Lands and the Vatican]. Brno: CDK.

Hoffmann, B. (1946). A kdo vas zabije... Zivot a utrpeni knezstva $v$ koncentracnich taborech [And Who Will Kill You... The Life and Suffering of the Priesthood in Concentration Camps]. Prerov: Spolecenske podniky v Prerove.

Kamenec, I., Precan, V., \& Skorvanek, S. (Ed.) (1992). Vatikan a Slovenska republika (19391945). Dokumenty [The Vatican and the Slovak Republic (1939-1945). Documents]. Bratislava: Slovak Academic Press.

Kaplan, K. (1993). Stat a cirkev v Ceskoslovensku v letech 1948-1953 [The State and the Church in Czechoslovakia in the Years 1948-1953]. Brno: Doplnek.

Karnik, Z. (2003), Ceske zeme v ere Prvni republiky (19/8-1938) [The Czech Lands in the Era of the First Republic], III. O preziti a o zivot (1936-1938). Prague: Libri.

Kmoch, P. (2018). Operace Anthropoid: Epilog. Atentat na Reinharda Heydricha ve svetle dobovych pramenu [Operation Anthropoid: Epilogue. The Assassination of Reinhard Heydrich in the Light of Contemporary Sources]. Prague: Academia.

Kukanova, Z. (20I4). Od tolerance k nepratelstvi. Diplomaticke vztahy Ceskoslovenska $s$ Vatikanem v letech 1945-1950 [From Tolerance to Hostility. Diplomatic Relations of Czechoslovakia with the Vatican in the Years 1945-1950]. Semper Paratus, 3, 20 I4. 5288.

Letz, R. (20I2). Slovenske dejiny [Slovak History], V. (1938-1945). Bratislava: Literarne informacne centrum.

Letz, R. (Ed.) (200I). Boli traja. Zbornik materialov z vedeckej konferencie o politickom procese so slovenskymi katolickymi biskupmi J. Vojtassakom, M. Buzalkom a P. Gojdicom $\checkmark$ Bratislave 19. januara 200I, doplneny o autenticke archivne dokumenty a fotografie [They Were Three. Proceedings from Scientific Conference on the Political Process with Slovakian Catholic Bishops J. Vojtassak, M. Buzalka, and P. Gojdic held in Bratislava on January 19, 200I, complemented by authentic archival documents and photographs], Bratislava: Zvaz protikomunistickeho odboja.

Letz, R. (Ed.) (2007). V hodine velkej skusky. Listy biskupa Michala Buzalku. Spolecne prejavy slovenskych katolickych biskupov. Subor dokumentov [At the hour of the great rehearsal. Letters of Bishop Michal Buzalka. Joint speeches of Slovak Catholic bishops. File of Documents]. Trnava: Spolok svateho Vojtecha.

Lora, E., \& Simionati, R. (Ed.) (1995). Enchiridion delle encicliche, V. [Pio XI (1922)]. Bologna: EDB. 
Ludvik, F. (1946). Ceske katolicke knezstvo s narodem a lidem $v$ boji, utrpeni a praci pro lepsi zitrek. Dokumenty, projevy, smernice [The Czech Catholic Priesthood with the Nation and the People in Struggle, Suffering and Work for a Better Tomorrow. Documents, speeches, directives]. Prague: Arcidiecezni pastoracni ustredi.

Machula, J. (1998). Vatikan a Ceskoslovensko (1938-1948). Pameti [Vatican and Czechoslovakia (1938-1948). Memoirs]. Prague: Ustav pro soudobe dejiny AV CR.

Nemecek, J. (2008). Soumrak a usvit ceskoslovenske diplomacie. 15. brezen 1939 a ceskoslovenske zastupitelske urady [Dusk and Dawn of Czechoslovak Diplomacy. March 15, 1938 and the Czechoslovak Embassies]. Prague: Academia.

Petruv, H. (20I I). Zakonne bezpravi. Zide v Protektoratu Cechy a Morava [Legal injustice. Jews in the Protectorate of Bohemia and Moravia]. Prague: Auditorium.

Rothkirchnenova, L., Schmidt-Hartmannova, E., \& Dagan, A. (I 991). Osud Zidu v protektoratu 1939-1945 [The Fate of the Jews in the Protectorate 1939-1945]. Prague: Trizonia.

Rychlik, J. (2012). Cesi a Slovaci ve 20. stoleti. Spoluprace a konflikty 1914-1992 [Czechs and Slovaks in the 20th century. Cooperation and conflicts 1914-1992]. Prague: Vysehrad.

Sebek, J. (2008). Papezska politika a ceske zeme 1938-1945 [Papal Politics and the Czech Lands 1938-1945]. Salve, I8 (3). 23-34.

Sebek, J. (20I4). Papezove moderniho veku. Vatikan od Pia IX. po Frantiska a jeho vztah $k$ ceskym zemim [Popes of Modern Age. Vatican from Pius IX to Francis and its Relation to the Czech Lands]. Ritka: Cas.

Smid, M. (20/4). Dramaticky osud apostolskeho nuncia Saveria Rittera $v$ obdobi nesvobody (1938-1945) [The Dramatic Fate of the Apostolic Nuncio Saverio Ritter During the Period of Imprisonment (1938-1945)]. In Tauchen, J., \& Schelle, K. (Ed.), Obdobi nesvobody (225-235). Ostrava: Key Publishing.

Smid, M. (20I5). Apostolsky nuncius v Praze. Vyznamny faktor v ceskoslovensko-vatikanskych vztazich v letech 1920-1950 [Apostolic Nuncio in Prague. A significant factor in CzechoslovakVatican relations in the years 1920-1950]. Brno: CDK.

Smid, M. (2016). Monsignor Otakar Svec. Zapomenuty pribeh spolupracovnika apostolske nunciatury v Praze [Monsignor Otakar Svec. A Forgotten Story of a Collaborator of the Apostolic Nunciature in Prague]. Cirkevni dejiny, 20 (9). 47-56.

Stribrny, J. (2009). Cirkve a nabozensky zivot za nacisticke okupace [Churches and Religious Life During the Nazi Occupation]. In: Mach, J. (Ed.), Vlastenectvi, cirkev a spolecnost $v$ promenach 19. a 20. stoleti. Prispevky z konference konane na pocest dvousteho vyroci narozeni vlasteneckeho kneze a regionalniho historika Josefa Mnohoslava Rostlapila dne 15. zari 2009 v Dobrusce. 93-142. Dobruska: Mesto Dobruska.

Sustek, V. (2019). Atentat na Reinharda Heydricha a druhe stanne pravo na uzemi tzv. protektoratu Cechy a Morava [The Assassination of Reinhard Heydrich and the Second Martial Law in the Territory of the so-called Protectorate of Bohemia and Moravia]. Prague: Scriptorium. 
Vasko, V. (1990). Neumlcena. Kronika katolicke cirkve $v$ Ceskoslovensku po druhe svetove valce [Unsilenced. Chronicle of the Catholic Church in Czechoslovakia after the World War II], II, Prague: Zvon.

Vasko, V. (2004). Dum na skale. Cirkev zkousena [House on a Rock. The Church Tested], I. (1945 - zacatek 1950), Kostelni Vydri: Karmelitanske nakladatelstvi.

Vass, M. (20II). Slovenska otazka v I. CSR (1918-1938) [The Slovakian Issue in the First CSR (19/8-1938)]. Martin: Matica slovenska.

Vodickova, S. (Ed.) (20I3). I zvire melo vice utrpnosti nez clovek. Pameti patera Frantiska Stveraka, vezne nacistickeho a komunistickeho rezimu [Even an Animal Had More Suffering Than a Human. Memoirs of Father Frantisek Stverak, a prisoner of the Nazi and Communist regime]. Prague: USTR.

Zapletalova, J. (20I I). Norbert Klein - posledni nemecky biskup v Brne a prvni klerikalni velmistr Radu nemeckych rytiru [Norbert Klein - the Last German Bishop in Brno and the First Clerical Grandmaster of the Order of the Teutonic Knights]. In Marek, P. (Ed.), Jan Sramek a jeho doba. Brno: CDK.

\section{Biographical note}

Prof. ThLic. Marek Smid, Ph.D. (1979) graduated in the fields of history, political science and theology. He currently works as an associate professor at the Department of Church and Literary History of the Catholic Theological Faculty of Charles University in Prague. He focuses on the Church history of the 19th and 20th century, especially the foreign policy of the Holy See. Furthermore, he is the author of 14 monographs and 100 professional history articles published in the Czech Republic and abroad. Since 2008 he has been systematically researching the Vatican archives. His recent monographs are Vatican and Soviet Communism 1917-1945 (in Czech, 2020) and Mission: Apostolic Nuncio in Prague. Czechoslovakian-Vatican Diplomatic Relations between 1920 and 1950 (in English, 2020). 